\title{
Evaluation of Some Female Jojoba Genotypes under Sandy Land Conditions Eltaweel, A. A. ${ }^{1}$; A. A. Aly ${ }^{1}$; T. K. El- Bol ok ${ }^{1}$ and Sh. M. Arafat ${ }^{2}$ ${ }^{1}$ Olive and Semi-Arid Zone Fruits Dept.,, Hort. Res. Inst., Agric. Res. Center (ARC), Egypt. ${ }^{2}$ Oil \&Fats Dept., Food Technol. Res. Inst., Agric. Res. Center (ARC), Giza, Egypt.
}

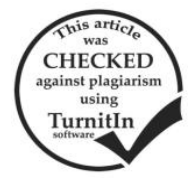

\section{ABSTRACT}

This investigation was carried out on female Jojoba (Simmondsia Chinensis, (Link) Schneider) shrubs in a private orchard at Hackstep, Zone, Cairo Governorate to evaluate 15 female shrubs, about 8 years old during two successive seasons of 2014 and 2015 . The shrubs growing in sandy soil in 4 lines at distances $3 \times 3$ meter apart and irrigated with drip irrigation system. Through the rigorous assessment of female selected jojoba trees through the measurements of vegetative growth, floral measurements, productivity and the percentage of oil in their seeds. The study recommends the following: Firstly: the strongest shrubs were No. (1, 2, 5, 9, 10, 12 and 15), secondly: the shrub number No 4 was the earliest one in the flowering date in both first and second seasons. Thirdly: the highest yield recorded for female shrubs No. $(5,10,12$ and 15) in the first season, while in the second one were No. 9 and 12 per the branch. Fourthly: the female shrubs No. (2, 5, 7 and 13) gave the highest oil content in the first season, while in the second one, the female shrub No. 11 was the best. Fifthly: genetic fingerprint of different species was made using 15 primers and it resulted in 5 positive primer and unaffected 10 then, when using ISSR marker the results showed that there are differences between breeds. It is clear from the foregoing that the shrubs No. $5,4,12$, and 11,13 ) were the best in the strength of growth, early harvest, production and oil content percentage and can be more vegetative and cultivated. As for a high value of genetic similarity was No. 8 and 6 and also, the highest similarity value $(0.875)$ was found between the strains (T8 and T6) followed by 0.792 between (T5 \& T15, T8 \& T13 and T11 \& T14), respectively. Generally, genetic similarity value was low among the investigated genotypes and the study.

\section{INTRODUCTION}

Jojoba pronounced "Ho-ho-ba" belongs to the genus (Simmondsia chinensis, (Link) Schneider) is in the family Simmondsiaceae, (Benzioni, 1995). It is native to the Sonoran and Mojave deserts of southern Arizona, south California, and northwestern Mexico. It was found that have climatic aspects of arid and semiarid regions, which are the suitable climate for jojoba shrubs growth and development (Ramonet-Razcon, 1986 and Milthorpe, 2006).

The total cultivated area of jojoba in Egypt reached about 26000 feddans its plantations are concentrated in El-Ismailia and Sinai south governorates. Jojoba is a small multi-stemmed tree that grows $6 \mathrm{~m}$, but usually around $2-2.5 \mathrm{~m}$, diocious (producing male and female optalous flowers on each separate plants. The jojoba fruit is a capsule of tan or brown in color at maturation stage. It contains one to three dark brown seeds; most of them at maturity vary in size and weight from 700 seeds $/ \mathrm{kg} 3500$ seeds $/ \mathrm{kg}$ (Hogan et al., 1980). Seeds contain about 50-60\% oil planting. Jojoba oil is characterized by cosmetic lipid materials, natural or synthetic and also, resists hydrolysis and oxidation for more effective. Planting jojoba shrubs in Egypt has a promising future as an industrial crop specially because of its low water requirements and its high tolerance to salinity, also its ability to be planted in the new reclaimed lands or uncultivated ones (Benzioni, 1997).

Many investigators evaluated various genotypes under different regions of Egypt, they found that vegetative growth, flowering and production (quantity and quality) varied from one genotype to another different years. Thus, the present investigation was carried out to study the morphological characteristics to introduce an accurate evaluation for 15 female shrub genotypes as well as, the objective of Electrophoretic analysis is to identify the degree of genetic relationship among the tested genotypes of jojoba. The field of Jojoba breeding is in important to select the elite parents that could be used in the prediction of the most desirable crosses.

\section{MATERIALS AND METHODS}

The present investigation was carried out in two successive seasons of 2014 and 2015 on 15 female jojoba shrubs at a private jojoba orchard located Hackstep Zone in Cairo Governorate, Egypt.

\section{Evaluation procedure :}

Trees were about 8 years old and established by using seeds, grown in sandy soil at Huckstep Zone. They were planted $3 \mathrm{~m}$ within rows and $3 \mathrm{~m}$ apart (466 shrubs /feddan). Drip irrigation system was adopted in this orchard. The trees were of the same age and grown under the same environmental and culture practices, such as weed and pest control pruning, irrigation and fertilization. The experiments were laid out in a randomized complete block design. Fifteen female shrubs were chosen to select the superior ones and each shrub treated individually.

Table 1. Physical and chemical properties of the experimental soil were

\begin{tabular}{lcccc}
\hline \multicolumn{1}{c}{ Physical properties } & \multicolumn{3}{c}{ Chemical properties } \\
\hline Sandy & $90.35 \%$ & \multicolumn{2}{c}{ Particle size distribution $(\%)$} \\
Silt & $3.00 \%$ & $\mathrm{EC}(\mathrm{mm} . / \mathrm{cm})$ & 1.14 \\
Clay & $6.65 \%$ & $\mathrm{pH}(1: 2.5)$ & 7.43 \\
Texture & Sandy & \multicolumn{2}{c}{$\mathrm{SP}$} & 17.50 \\
\hline Available macro and & micro elements & & $\mathrm{Ca}^{+}$ & 3.55 \\
$\mathrm{~N}(\mathrm{mg} / \mathrm{kg})$ & 144.55 & Cations & $\mathrm{Mg}^{++}$ & 1.50 \\
$\mathrm{P}(\mathrm{mg} / \mathrm{kg})$ & 15.22 & (meq./L) & $\mathrm{Na}^{+}$ & 5.85 \\
$\mathrm{~K}(\mathrm{mg} / \mathrm{kg})$ & 115.02 & & $\mathrm{~K}^{+}$ & 0.49 \\
$\mathrm{Fe}(\mathrm{mg} / \mathrm{kg})$ & 3.28 & & $\mathrm{HCO}^{-}$ & 1.00 \\
$\mathrm{Mn}(\mathrm{mg} / \mathrm{kg})$ & 1.35 & Anions & $\mathrm{Cl}^{-}$ & 9.50 \\
$\mathrm{Zn}(\mathrm{mg} / \mathrm{kg})$ & 1.19 & (meq./L) & $\mathrm{SO}_{4}^{--}$ & 0.89 \\
$\mathrm{Cu}(\mathrm{mg} / \mathrm{kg})$ & 0.62 & & $\mathrm{CO}_{3}^{--}$ & - \\
\hline
\end{tabular}

$\mathbf{E C}=$ Electrical conductivity.

$\mathrm{SP}=$ Saturation percentage.

\section{Morphological studies.}

\section{A- Height $\left(\mathrm{m}^{3}\right)$, circumference $\left(\mathrm{m}^{3}\right)$, growth vigour and} habit of shrub:

Height, stem diameter, circumference, growth vigor and habit of each shrub were measured at the end of both growing seasons on October of 2014 and 2015. 
Eltaweel, A. A. et al.
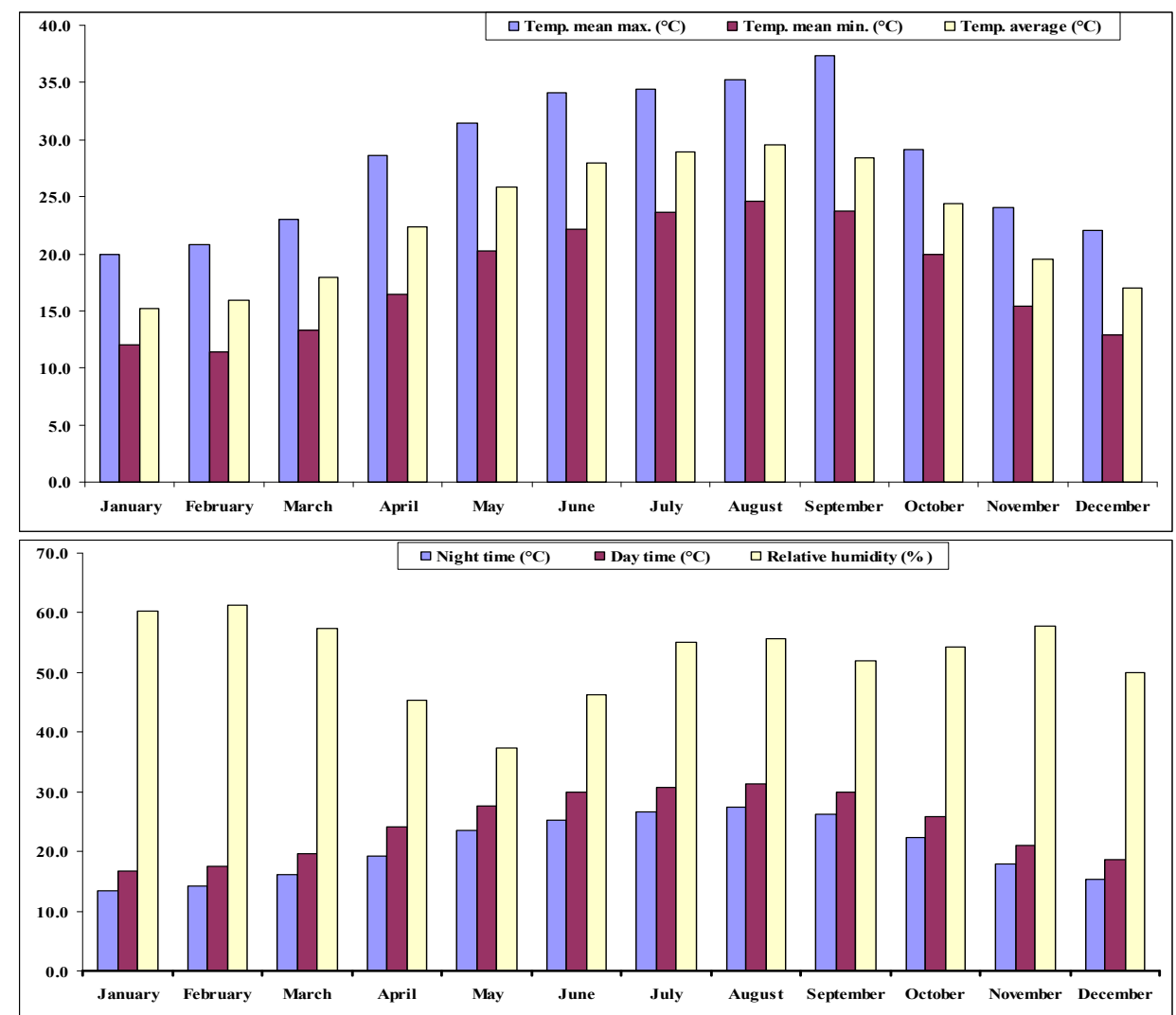

Fig. 1. Average monthly temperature (Temp.) and relative humidity (\%) of Jojoba in Huckstep orchard during the study from 2014 season.

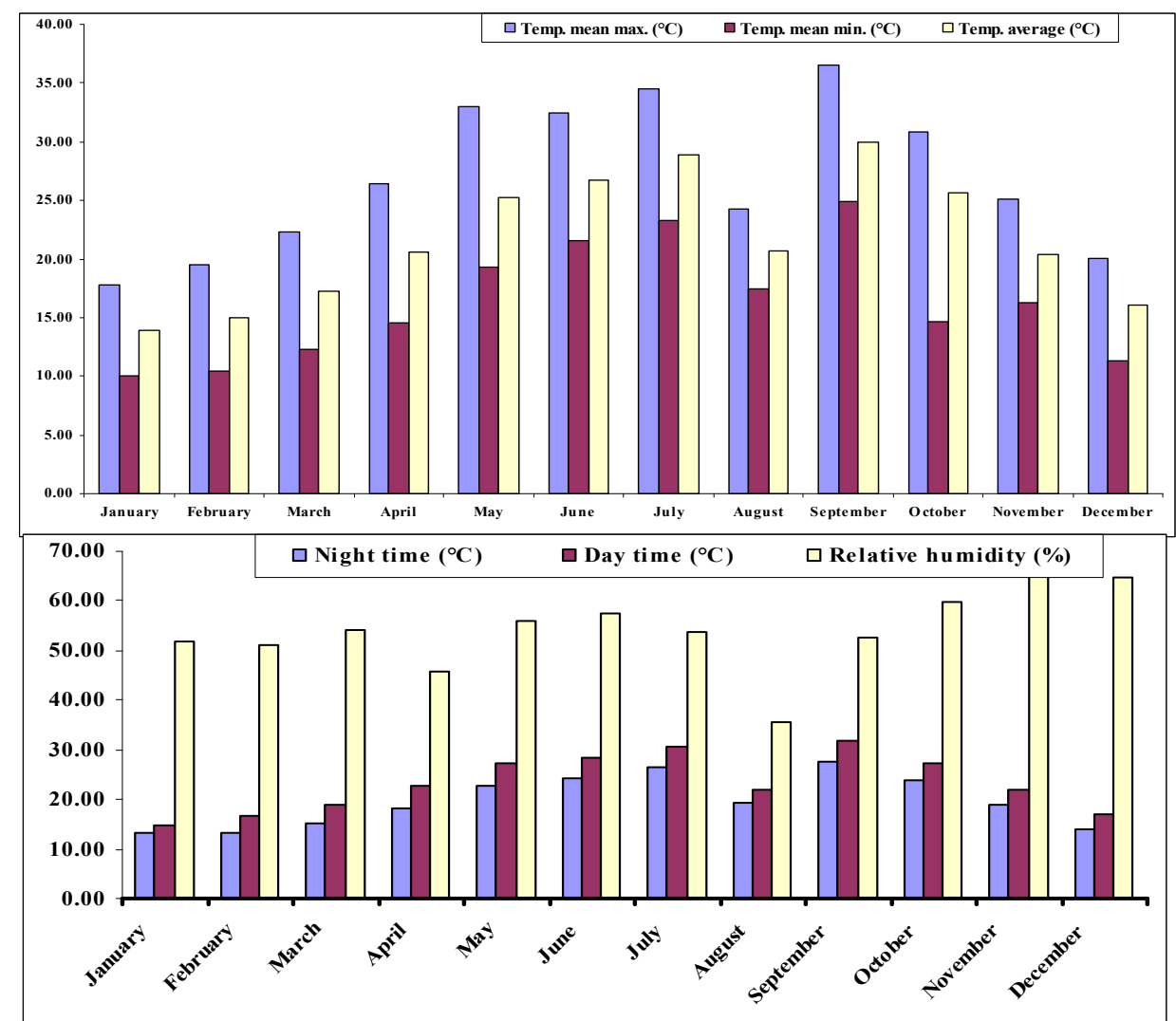

Fig. 2. Average monthly temperature (Temp.) and relative humidity (\%) of Jojoba in Huckstep orchard during the study from 2015 season. 


\section{B-Number of leaves per shoot:}

The number of leaves per shoot was counted on the labeled branches and calculated per meter; samples of 30 leaves (The $4^{\text {th }}$ and $5^{\text {th }}$ leaves from the top of the brunch) were collected from different directions of shrub to use for the following measurements at the end of first and second seasons (Chen, et al., 1985; Kohorn, 1994 \& 1995 and Hassan, 2007)

3- Leaf area $\left(\mathrm{cm}^{2}\right)$ :

The leaf surface was estimated from the following equation:

Leaf area $=0.717 \times-0.095$, which $\times$ is the product of length by width. (Chen, et al. 1985 \& Kohorn, 1994 and 1995).

The results were expressed as an average leaf area per shoot per shrub.

3-1- leaf $L / W$ ratio $=$ leaf length $/$ leaf width

C-Shoot length $(\mathrm{cm})$ and leaf characteristics.

Ten shoots were randomly selected at different sides on each female shrub/genotypes labeled and used to study the following characteristics.

1-Shoot length $(\mathrm{cm})$

Length of the growing shoots was measured for each shrub at the end of growing seasons.

2- No. of laterals/shoot.

The number of laterals per shoot was counted at the end of both growing seasons.

3 -Stem diameter $=$ one Stem diameter was determined per meter length of Stem.

4- No. of internodes of the shoot.

Average No. of internodes was determined per one meter length of shoot.

\section{D-Leaf pigments}

At the first week of August in both seasons, 50 mature leaves per replicate were collected from the medium position of the current season's shoots. Chlorophyll A, B and carotenoids were determined in fresh leaves samples calorimetrically at wave length of 660, 640 and $440 \mathrm{~nm}$ respectively according to AOAC (2012).

E-Flowering and fruiting characteristics

Ten shoots were randomly selected at different sides on each female shrub, labeled and used to study the following flowering and fruiting characteristics:

\section{1- Flowering date of jojoba shrubs}

In both seasons, it was assessed during flowering period per shrub (from First of Feb).

\section{2- Number of flowers:}

The number of flowers which was counted by number flowers on selected branches which tagged before flowering stage.

\section{3- Number of fruits}

In both seasons of study it was assessed during fruiting period shrub (from 1-May to 1-July).

F- Seed Yield, seed length, seed width and seed weight. Yield $/$ shrub $(\mathrm{kg})$ was recorded at the harvesting date for every shrub.

The seeds are considered fruits in jojoba shrubs. They were harvested at the harvesting date for each shrub solely.

Seed length and seed width in $\mathrm{cm}$ were determined of per meter, seed weight in gm,

G- Determination of ridges, No. grooves, oil and moisture content:

1 -Number of ridges and grooves were calculated.
2-The moisture content was determined according to the method of the Association of Official Analytical Chemists (AOAC, 2012) by drying the samples in an oven at $105^{\circ} \mathrm{C} \pm 5^{\circ} \mathrm{C}$ to constant weight.

\section{3- Determination of total lipids:}

Jojoba seeds were crushed separately several times in an experimental mill, and dried in an oven at $70^{\circ} \mathrm{C}$ for 6 hours. Then the crude lipids content in the samples were determined according to the procedure by AOAC (2012). Whereas known weight of dry sample $(10 \mathrm{~g})$ was finally grinded and extracted with N-hexane (b.p. $60-70^{\circ} \mathrm{C}$ ) using Soxhelt apparatus. The solvent was removed and the percentage of total lipids was calculated.

\section{H- Polymerase Chain Reaction (PCR).}

In order to obtain clear reproducible amplification products, different preliminary experiments were carried out in which a number of factors were optimized. These factors included PCR temperature cycle profile and concentration of each of the template DNA, primer, $\mathrm{MgCl}$ and Taq polymerase. A total of fifteen random DNA oligonucleotide primers were independently used according to Williams et al. (1990) in the PCR reaction. Only five primers succeeded to generate reproducible polymorphic DNA products. The PCR amplification was performed in a $25 \mu \mathrm{l}$ reaction volume containing the following: $2.5 \mu \mathrm{l}$ of dNTPs $(2.5 \mathrm{~mm})$, $1.5 \mu \mathrm{l}$ of $\mathrm{Mg} \mathrm{Cl} 2(25 \mathrm{~mm}), 2.5 \mu \mathrm{l}$ of $10 \mathrm{x}$ buffer, $2.0 \mu \mathrm{l}$ of primer $(2.5 \mu \mathrm{M}), 2.0 \mu \mathrm{l}$ of template DNA $(50 \mathrm{ng} / \mu \mathrm{l}), 0.3 \mu \mathrm{l}$ of Taq polymerase $(5 \mathrm{U} / \mu \mathrm{l})$ and $14.7 \mu \mathrm{l}$ of sterile ddH2O. The reaction mixtures were overlaid with a drop of light mineral oil per sample. Amplification was carried out in Techni TC-512 PCR System. The reaction was subjected to one cycle at $95^{\circ} \mathrm{C}$ for 5 minutes, followed by 35 cycles at 96 ${ }^{\circ} \mathrm{C}$ for 30 seconds, $37^{\circ} \mathrm{C}$ for 30 seconds, and $72{ }^{\circ} \mathrm{C}$ for 30 seconds, then a final cycle of $72{ }^{\circ} \mathrm{C}$ for 5 minutes. PCR products were run at $100 \mathrm{~V}$ for one hour on $1.5 \%$ agarose gels to detect polymorphism between the jojoba strains under study. Only five primers succeeded to generate reproducible polymorphic DNA products. Table (2) lists the base sequences of these DNA primers that produced informative polymorphic bands. The PCR products were separated on a $1.5 \%$ agarose gels and fragments sizes were estimated with the $100 \mathrm{bp}$ ladder marker $(1500,1000,900$, $800,700,600,500,400,300,200$ and 100bp).

\section{Statistical analysis:}

The DNA bands generated by each primer were counted and their molecular sizes were compared with those of the DNA markers. The bands scored from DNA profiles generated by each primer were pooled together. Then the presence or absence of each DNA band was treated as a binary character in a data matrix (coded 1 and 0 , respectively) to calculate genetic similarity and to construct dendrogram tree among the studied strains. Calculation was achieved using Dice similarity coefficients (Dice, 1945) as implemented in the computer program SPSS-10.

Table 2. The primer names and their nucleotide sequences list used in this investigation for RAPD procedure.

\begin{tabular}{lll}
\hline No & Primer code & \multicolumn{1}{c}{ Sequence } \\
\hline 1 & OP-A07 & 5'GAAACGGGTG3' \\
2 & OP-A18 & 5'AGGTGACCGT3' \\
3 & OP-C04 & 5'CCGCATCTAC3 \\
4 & OP-C19 & 5 GTTGCCAGCC3 \\
$5-$ & OP-Z03 & 5 CAGCACCGCA3 \\
\hline
\end{tabular}


Statistical analysis:

The obtained data of 2014 and 2015 experimental seasons were analyzed according to the methods described by Snedecor and Cochran (1980) and differences between shrubs were compared by using Duncan multiple tests as recorded by Duncan (1955).

\section{RESULTS AND DISCUSSION}

A-Vegetative growth characters of shrubs:

1- Growth vigor:

Data presented in Table 3 showed that shrubs No. 1, $2,5,9,10,12$ and 15 had a strong growth, whereas Shrubs No.3, 4, 6, 7, 8, 11, 13 and 14 had a medium growth.

\section{2- Growth habit:}

As presented in Table 3, it is clear that most of the studied shrubs had a spread growth habit, while only five shrubs No.3,10 and 14 had a straight growth habit whereas shrubs No. 4 and 7 was dropping growth. This characterization can be coinciding with the bases of identification (Abou El-Khashab et al., 2007 and El-Sayed, 2010 ) it is known that Jojoba is a dioecious, crosspollinated species (Gentry, 1058). This result in high variability in most characteristics between the different jojoba genotypes (Abou El-Khashab et al., 2007)

\section{3-Shrub height:}

It's clear from the concerned data in Table 3 that shrub No.1 measured the highest values in shrub length with $(3.00$ and $3.10 \mathrm{~m})$ followed by these of No. $(12,10$ and 14), while shrub No. $(9,13)$ had the lowest values $(1.67 \& 1.90 \mathrm{~m})$ in 2014 \& 2015 seasons respectively. Local jojoba and seeded plantations over the world show great variability among plants (Palzkill1987).

Table 3. Vegetative growth measurements, growth vigor, growth habit, shrub height $(\mathrm{m} 3)$ and Shrub circumference $(\mathrm{m} 3)$ in the 15 trees females Jojoba shrubs in 2014 \& 2015 seasons.

\begin{tabular}{|c|c|c|c|c|c|c|}
\hline \multirow{2}{*}{$\begin{array}{l}\text { No. of } \\
\text { shrubs }\end{array}$} & \multirow{2}{*}{$\begin{array}{c}\text { Growth } \\
\text { vigor }\end{array}$} & \multirow{2}{*}{$\begin{array}{c}\text { Growth } \\
\text { habit }\end{array}$} & \multicolumn{2}{|c|}{ Shrub } & $\begin{array}{r}\text { Sh } \\
\text { circumfe }\end{array}$ & $\bar{b}$ \\
\hline & & & & & 2014 & 2015 \\
\hline 1 & Strong & Spread & 3.00 & 3.10 & 3.10 & 4.00 \\
\hline 2 & Stro & & 1.70 & 2.50 & 4.70 & 5.00 \\
\hline & Medi & & 2.20 & 2.24 & 3.67 & 4.00 \\
\hline 4 & & Dro & 2.00 & 2.23 & 5.60 & 7.00 \\
\hline 5 & Strc & & 1.40 & 1.70 & 3.70 & 5.20 \\
\hline & $\mathrm{Me}$ & & 1.73 & 2.00 & 3.64 & 4.00 \\
\hline & $\mathrm{Me}$ & Drot & 2.10 & 2.45 & 5.50 & 6.00 \\
\hline & Medi & Spread & 2.00 & 2.27 & 3.10 & 4.00 \\
\hline & $\mathrm{Str}$ & & 1.67 & 1.90 & 4.25 & 5.00 \\
\hline 0 & Strong & Straight & 2.30 & 2.37 & 7.10 & 8.20 \\
\hline & Medium & & 1.70 & 2.4 & 6.97 & 8.00 \\
\hline & Stro & & 2.80 & 2.9 & 4.80 & 6.00 \\
\hline & Medium & Spre & 1.70 & 1.90 & 3.92 & 4.00 \\
\hline & Medium & Strai & 2.30 & 2.4 & 7.30 & 7.60 \\
\hline & Strong & Spread & 2.00 & 2.30 & 4.80 & 5.80 \\
\hline
\end{tabular}

\section{4-Shrub circumference:}

From the data in Table 3 indicted also that shrub No. $4,10,11$ and 14 had the highest circumference $(5.60 \&$ $7.00 \mathrm{~m}),(7.10 \& 8.20 \mathrm{~m}),(6.97 \& 8.00 \mathrm{~m}),(7.30 \& 7.60$ m), while shrubs No. (1, 2, 3, 5, 6, 7, 8, 9, 12, 13 and 15) had the lowest circumference in both seasons respectively, whereas the rest genotypes were in between. Ayanoglu (2000) on Jojoba and Hosseini et al., (2004) on olive, reported that morphological and biological characters are used to evaluate germplasm cultivars. These result can be coincide with the base of identification described by Ayerza (1996) and Botti et al. (1996 \& 1998) on Jojoba evaluation. Ramonet-Razcon, (1988) showed that the cultivated jojoba communities propagated by seed, are composed of multiple genotypes.

B-Characterizes of leaves per shoot:

\section{1-Number of leaves:}

Data in Table 4 indicated that, there was an obvious significant different among studied shrubs; the tree No. 11 has the highest number of leaves/shoot (65.90) in the first season, while in the second season the highest value was No. 6.(47.00), Botti et al. (1998) mentioned that the variations in the morphological parameters such as; number of leaves were due to genetic variations.

\section{2- Leaf area $\left(\mathrm{m}^{2}\right)$ and Leaf $L / W$ ratio}

Results in Table 4 showed that significant variations occurred among parameters of the jojoba trees in the present study. The highest values of leaf area were shown with genotype No.13 in the first season, while in the second season was obtained in shrub No.3. The shrub No. 6 has the highest values of Leaf L/W ratio in the first season. Whereas shrub No. 12 and14 has the highest number in the second season. Botti et al. (1998) found that all leaf parameters s showed differences among clones; leaf area and Leaf $\mathrm{L} / \mathrm{W}$ ratio.

Table 4. Measurement of leaves No., leaf area $\left(\mathrm{cm}^{2}\right)$ and leaf $L / W$ ratio in the 15 trees females Jojoba shrubs in 2014 \& 2015 seasons.

\begin{tabular}{l|c|c|c|c|c|c|c|}
\hline $\begin{array}{l}\text { No. of } \\
\text { shrubs }\end{array}$ & $\begin{array}{c}\text { No. of } \\
\text { leaves }\end{array}$ & $\begin{array}{c}\text { Leaf area } \\
\text { (cm }^{2} \text { ) }\end{array}$ & $\begin{array}{c}\text { Leaf L/W } \\
\text { ratio }\end{array}$ \\
\hline 1 & $\mathbf{2 0 1 4}$ & $\mathbf{2 0 1 5}$ & $\mathbf{2 0 1 4}$ & $\mathbf{2 0 1 5}$ & $\mathbf{2 0 1 4}$ & $\mathbf{2 0 1 5}$ \\
\hline & $55.55 \mathrm{~cd}$ & $38.27 \mathrm{c}$ & $3.14 \mathrm{ef}$ & $5.46 \mathrm{e}$ & $2.35 \mathrm{ef}$ & $2.14 \mathrm{de}$ \\
\hline & $53.60 \mathrm{~d}$ & $27.78 \mathrm{fg}$ & $4.09 \mathrm{c}-\mathrm{e}$ & $7.03 \mathrm{~cd}$ & $2.53 \mathrm{c}-\mathrm{e}$ & $2.21 \mathrm{de}$ \\
4 & $48.02 \mathrm{f}$ & $34.22 \mathrm{~d}$ & $5.01 \mathrm{bc}$ & $9.38 \mathrm{a}$ & $2.31 \mathrm{ef}$ & $2.07 \mathrm{ef}$ \\
5 & $45.47 \mathrm{~g}$ & $37.77 \mathrm{c}$ & $5.60 \mathrm{~b}$ & $6.53 \mathrm{~d}$ & $2.37 \mathrm{~d}-\mathrm{f}$ & $2.22 \mathrm{de}$ \\
6 & $48.85 \mathrm{ef}$ & $40.11 \mathrm{c}$ & $3.97 \mathrm{de}$ & $5.39 \mathrm{e}$ & $2.34 \mathrm{ef}$ & $2.06 \mathrm{ef}$ \\
7 & $60.48 \mathrm{~b}$ & $47.00 \mathrm{a}$ & $4.17 \mathrm{c}-\mathrm{e}$ & $6.53 \mathrm{~d}$ & $2.95 \mathrm{a}$ & $2.55 \mathrm{~b}$ \\
8 & $42.97 \mathrm{~g}$ & $43.00 \mathrm{~b}$ & $3.66 \mathrm{~d}-\mathrm{f}$ & $5.27 \mathrm{e}$ & $2.81 \mathrm{ab}$ & $2.54 \mathrm{~b}$ \\
9 & $50.92 \mathrm{e}$ & $25.83 \mathrm{hi}$ & $3.24 \mathrm{ef}$ & $4.62 \mathrm{e}$ & $2.79 \mathrm{ab}$ & $2.51 \mathrm{bc}$ \\
10 & $56.48 \mathrm{c}$ & $31.89 \mathrm{e}$ & $2.56 \mathrm{~d}-\mathrm{f}$ & $6.76 \mathrm{~cd}$ & $2.62 \mathrm{~b}-\mathrm{d}$ & $1.88 \mathrm{f}$ \\
11 & $48.17 \mathrm{f}$ & $30.67 \mathrm{ef}$ & $3.24 \mathrm{ef}$ & $5.13 \mathrm{e}$ & $2.56 \mathrm{~b}-\mathrm{e}$ & $2.30 \mathrm{~d}$ \\
12 & $65.90 \mathrm{a}$ & $28.22 \mathrm{gh}$ & $3.67 \mathrm{~d}-\mathrm{f}$ & $6.88 \mathrm{~cd}$ & $2.66 \mathrm{bc}$ & $2.61 \mathrm{~b}$ \\
13 & $57.93 \mathrm{bc}$ & $20.22 \mathrm{j}$ & $2.77 \mathrm{f}$ & $3.35 \mathrm{f}$ & $2.48 \mathrm{c}-\mathrm{e}$ & $2.94 \mathrm{a}$ \\
14 & $48.85 \mathrm{ef}$ & $23.67 \mathrm{i}$ & $6.98 \mathrm{a}$ & $7.65 \mathrm{bc}$ & $2.69 \mathrm{bc}$ & $2.29 \mathrm{~d}$ \\
15 & $43.07 \mathrm{~g}$ & $20.44 \mathrm{j}$ & $3.82 \mathrm{~d}-\mathrm{f}$ & $4.82 \mathrm{e}$ & $2.38 \mathrm{~d}-\mathrm{f}$ & $2.81 \mathrm{a}$ \\
\hline
\end{tabular}

Values in the same column having different letters showed statistically significant differences $(P<0.05)$.

\section{C- Characterizes of shoot length, No. of laterals/shoo, stem diameter and No. of internodes:}

Data in Table 5 revealed that the highest average of shoot length was apparent in female shrubs No.14 in the first season, while the highest shoot length in the second one was in female shrubs No.1, 4 and 11. Concerning No. of laterals/shoot, female shrubs No. 11 recorded the highest values for number of laterals/shoot in the first season. While in the second one the highest No. of laterals/shoot recorded for No. 5,10,11,12,13 and 14. Regarding the stem diameter, the highest values of stem diameter was recorded in female shrubs No. 3, 4, 6, 8, 9, 10, 11, 14 and 15 in the first season. Whereas the female shrub No. 4 had the highest value in the second one. As for No. of internodes, the highest No. of internodes was recorded in female No.4 in the both seasons. Botti et al. (1998); Benzioni et al. (1999) and El-Sayed (2010), they mentioned that different shrubs of jojoba varied greatly in their growth rate that appeared clear from length of their shoots and number of internodes. 
Table 5. Measurements of shoot length, No. of laterals/shoot stem diameter and No. of internodes: in the 15 trees females Jojoba shrubs during seasons 2014 \& 2015.

\begin{tabular}{|c|c|c|c|c|c|c|c|c|}
\hline \multirow{2}{*}{$\begin{array}{l}\text { No. of } \\
\text { shrubs }\end{array}$} & \multicolumn{2}{|c|}{ Shoot length (cm) } & \multicolumn{2}{|c|}{ No. of laterals/shoot } & \multicolumn{2}{|c|}{ Stem diameter (cm) } & \multicolumn{2}{|c|}{ No. of Internodes } \\
\hline & 2014 & 2015 & 2014 & 2015 & 2014 & 2015 & 2014 & 2015 \\
\hline 1 & $40.42 \mathrm{~d}-\mathrm{f}$ & $38.33 a$ & $2.44 \mathrm{fg}$ & $2.89 \mathrm{bc}$ & $0.200 \mathrm{~b}$ & $0.250 \mathrm{bc}$ & $7.83 \mathrm{~d}$ & $8.17 \mathrm{e}-\mathrm{g}$ \\
\hline 2 & $42.22 \mathrm{~cd}$ & $25.61 \mathrm{e}$ & $2.05 \mathrm{~g}$ & $2.50 \mathrm{c}$ & $0.217 \mathrm{~b}$ & $0.300 \mathrm{ab}$ & $8.67 \mathrm{~d}$ & $8.33 \mathrm{~d}-\mathrm{g}$ \\
\hline 3 & $45.58 \mathrm{bc}$ & $31.33 \mathrm{~b}$ & $2.00 \mathrm{~g}$ & $2.39 \mathrm{c}$ & $0.300 \mathrm{a}$ & $0.283 a-c$ & $9.00 \mathrm{~d}$ & $9.50 c-e$ \\
\hline 4 & $47.32 \mathrm{ab}$ & $40.55 \mathrm{a}$ & $2.39 \widehat{\mathrm{fg}}$ & $2.67 \mathrm{c}$ & $0.300 \mathrm{a}$ & $0.317 \mathrm{a}$ & $13.67 \mathrm{a}$ & $13.50 \mathrm{a}$ \\
\hline 5 & $37.94 \mathrm{e}-\mathrm{g}$ & $29.44 \mathrm{~b}-\mathrm{d}$ & $5.67 \mathrm{~b}$ & $4.17 \mathrm{a}$ & $0.217 \mathrm{~b}$ & $0.233 \mathrm{c}$ & $8.00 \mathrm{~d}$ & $7.33 \mathrm{~g}$ \\
\hline 6 & $43.97 \mathrm{~b}-\mathrm{d}$ & $32.44 b$ & $2.50 \mathrm{fg}$ & $2.66 \mathrm{c}$ & $0.283 a$ & $0.283 a-c$ & $12.00 \mathrm{~b}$ & $12.00 \mathrm{~b}$ \\
\hline 7 & $37.22 \mathrm{fg}$ & $30.11 b c$ & $3.33 \mathrm{~d}-\mathrm{f}$ & $2.66 \mathrm{c}$ & $0.217 \mathrm{~b}$ & $0.283 a-c$ & $2.83 \mathrm{ab}$ & $12.67 \mathrm{ab}$ \\
\hline 8 & $42.42 \mathrm{~cd}$ & $26.11 \mathrm{de}$ & $2.66 \mathrm{e}-\mathrm{g}$ & $2.89 \mathrm{bc}$ & $0.300 \mathrm{a}$ & $0.283 a-c$ & $9.17 \mathrm{~d}$ & $9.22 \mathrm{c}-\mathrm{f}$ \\
\hline 9 & $42.39 \mathrm{~cd}$ & $27.34 c-e$ & $4.33 \mathrm{~cd}$ & $3.89 \mathrm{ab}$ & $0.300 \mathrm{a}$ & $0.300 \mathrm{ab}$ & $9.00 \mathrm{~d}$ & $9.83 \mathrm{~cd}$ \\
\hline 10 & $42.12 \mathrm{~cd}$ & $21.78 \mathrm{f}$ & $5.33 \mathrm{bc}$ & $5.00 \mathrm{a}$ & $0.333 \mathrm{a}$ & $0.283 \mathrm{a}-\mathrm{c}$ & $8.50 \mathrm{~d}$ & $7.78 \mathrm{fg}$ \\
\hline 11 & $43.75 b-d$ & $40.83 a$ & $7.08 \mathrm{a}$ & $4.66 \mathrm{a}$ & $0.283 a$ & $0.267 \mathrm{a}-\mathrm{c}$ & $9.17 \mathrm{~d}$ & $9.44 \mathrm{c}-\mathrm{e}$ \\
\hline 12 & $41.71 \mathrm{c}-\mathrm{e}$ & $17.00 \mathrm{~g}$ & $3.55 \mathrm{~d}-\mathrm{f}$ & $4.22 \mathrm{a}$ & $0.217 b$ & $0.283 \mathrm{a}-\mathrm{c}$ & $8.17 \mathrm{~d}$ & $8.00 \mathrm{e}-\mathrm{g}$ \\
\hline 13 & $41.66 \mathrm{c}-\mathrm{e}$ & $24.11 \mathrm{ef}$ & $5.44 \mathrm{bc}$ & $4.55 \mathrm{a}$ & $0.217 \mathrm{~b}$ & $0.267 \mathrm{a}-\mathrm{c}$ & $8.00 \mathrm{~d}$ & $7.77 \mathrm{fg}^{\circ}$ \\
\hline 14 & $49.50 \mathrm{a}$ & $17.78 \mathrm{~g}$ & $3.78 \mathrm{de}$ & $4.11 \mathrm{a}$ & $0.333 \mathrm{a}$ & $0.267 \mathrm{a}-\mathrm{c}$ & $8.83 \mathrm{~d}$ & $8.00 \mathrm{e}-\mathrm{g}$ \\
\hline 15 & $35.68 \mathrm{~g}$ & $25.22 \mathrm{ef}$ & $2.83 \mathrm{e}-\mathrm{g}$ & $3.00 \mathrm{bc}$ & $0.300 \mathrm{a}$ & $0.267 \mathrm{a}-\mathrm{c}$ & $10.50 \mathrm{c}$ & $10.00 \mathrm{c}$ \\
\hline
\end{tabular}

Values in the same column having different letters showed statistically significant differences $(P<0.05)$.

\section{D-Chlorophyll A, B and Carotenoids.}

The results for chlorophyll A, B and carotenoids in Table 6 revealed that female shrub No. 3 recorded the highest values for Chlorophyll A during both seasons while the highest values of Chlorophyll B recorded for female No. 2 in the first seasons and second seasons. Regarding the Carotenoids, the highest values recorded for No.5 in the first and second seasons. These results are in line with this reported by Al-Ani et al. (1972), who found differences in photosynthetic capacities among jojoba from different populations.

Table 6. Chlorophyll (a \& b) and carotenoids in the $\mathbf{1 5}$ trees females Jojoba shrubs during seasons 2014\&2015

\begin{tabular}{|c|c|c|c|c|c|c|}
\hline \multirow{2}{*}{$\begin{array}{l}\text { No. of } \\
\text { shrubs }\end{array}$} & \multicolumn{2}{|c|}{ Chlorophyll a } & \multicolumn{2}{|c|}{ Chlorophyll b } & \multicolumn{2}{|c|}{ Carotenoids } \\
\hline & 2014 & 2015 & 2014 & 2015 & 2014 & 2015 \\
\hline & $0.330 \mathrm{c}$ & $0.350 \mathrm{c}$ & $0.270 \mathrm{~d}$ & $0.280 \mathrm{~b}$ & $0.013 \mathrm{~cd}$ & $0.007 \mathrm{c}$ \\
\hline & $0.380 \mathrm{ab}$ & $0.410 \mathrm{a}$ & $0.327 \mathrm{a}$ & $0.333 a$ & & $0.010 \mathrm{bc}$ \\
\hline & $0.390 \mathrm{a}$ & $0.400 \mathrm{a}$ & $0.317 \mathrm{ab}$ & $0.320 \mathrm{a}$ & & $0.040 \mathrm{a}$ \\
\hline & $0.330 \mathrm{c}$ & $3600 \mathrm{bc}$ & 8.200 & 0.2000 & & $0 \angle 0 b$ \\
\hline & $0.260 \mathrm{e}$ & $0.280 \mathrm{~d}$ & $0.207 \mathrm{e}$ & $0.213 \mathrm{c}$ & 0.0 & $0.040 \mathrm{a}$ \\
\hline & $0.240 \mathrm{f}$ & & $0.200 \mathrm{ef}$ & $0.207 \mathrm{c}$ & & \\
\hline & $240 \mathrm{f}$ & $0.250 \mathrm{f}$ & $0.180 \mathrm{fg}$ & $0.200 \mathrm{c}$ & & $\mathrm{Ob}$ \\
\hline & $0.370 \mathrm{~b}$ & $0.370 \mathrm{~b}$ & $0.300 \mathrm{bc}$ & $0.323 a$ & $0.027 a-c$ & $0.013 \mathrm{~b}$ \\
\hline & $0.210 \mathrm{~g}$ & $0.220 \mathrm{~g}$ & $0.100 \mathrm{j}$ & $0.107 f$ & $0.010 \mathrm{~d}$ & $0.007 \mathrm{c}$ \\
\hline & $0.200 \mathrm{~g}$ & $0.207 \mathrm{~g}$ & $0.160 \mathrm{gh}$ & $0.170 \mathrm{~d}$ & 0.03 & $0.027 \mathrm{a}$ \\
\hline & $0.230 \mathrm{f}$ & $0.240 \mathrm{f}$ & $0.150 \mathrm{~h}$ & 0.1 & & $0.020 \mathrm{~b}$ \\
\hline & $0.310 \mathrm{~d}$ & $0.273 d$ & 0.2 & & & \\
\hline & & & & & & \\
\hline & & & & & & \\
\hline & & & & & & \\
\hline
\end{tabular}

Values in the same column having different letters showed statistically significant differences $(P<0.05)$.

\section{E- Flowering and fruiting characteristics:}

\section{1- Flowering date of jojoba shrubs:}

Data tabulated in Table 7 showed the variation among in their fruit ripening dates. Flowering date of jojoba shrubs started between $1 / 2$ to $17 / 2$ in season 2014 and between $4 / 2$ to $22 / 2$ in season 2015 , it was cleared that shrub No. 4 was the earliest one in start of flowering during both seasons, and No.11 was the lasted one in the first and second seasons. These results are supported by the previous findings of Ahmed, (1989), who reported that the seed maturation in Egypt take period extend about five months after pollination.

\section{2- Number of flowers:}

Data as shown in Table 7 represent the number of flowers of female studied jojoba shrubs in 2014 and 2015 seasons. From this table it was cleared that the shrubs No.5, 9 and 15 had the highest values of flowers in the first season. Whereas in the second season, the highest values recorded with shrub No.7. These results are in line with Botti et al. (1996); Howson, (1985) and El-Said, (2010), who found that, number of flowers was dependent on genotypes.

3-Number of fruits:

As shown in Table 7, the shrub No. 5 and 15 gave the highest number of fruits in the first season. While, the shrub No. 7 was the highest number of fruits in the second season. In this concern, Benzioni et al. (1999) indicated that the number of fruits is affected to a great extent by environmental conditions and pollination.

Table 7. Measurements of start of flowering, No. of flowers and No. of fruits in the 15 trees females Jojoba shrubs in seasons 2014 \& 2015.

\begin{tabular}{l|l|l|l|l|l|l|}
\hline $\begin{array}{l}\text { No. of } \\
\text { shrubs }\end{array}$ & $\begin{array}{c}\text { Start of } \\
\text { flowering }\end{array}$ & \multicolumn{2}{|c|}{$\begin{array}{c}\text { No. of } \\
\text { flowers }\end{array}$} & \multicolumn{2}{|c|}{$\begin{array}{c}\text { No. of } \\
\text { fruits }\end{array}$} \\
\cline { 2 - 6 } & $\mathbf{2 0 1 4}$ & $\mathbf{2 0 1 5}$ & $\mathbf{2 0 1 4}$ & $\mathbf{2 0 1 5}$ & $\mathbf{2 0 1 4}$ & $\mathbf{2 0 1 5}$ \\
\hline 1 & $4 / 2$ & $6 / 2$ & $10.37 \mathrm{ab}$ & $9.44 \mathrm{ef}$ & $9.11 \mathrm{bc}$ & $8.17 \mathrm{~d}$ \\
2 & $4 / 2$ & $8 / 2$ & $8.22 \mathrm{~cd}$ & $9.61 \mathrm{ef}$ & $6.72 \mathrm{ef}$ & $8.33 \mathrm{~d}$ \\
3 & $4 / 2$ & $7 / 2$ & $8.61 \mathrm{~cd}$ & $10.94 \mathrm{c}-\mathrm{e}$ & $7.10 \mathrm{~d}-\mathrm{f}$ & $9.50 \mathrm{~cd}$ \\
4 & $1 / 2$ & $4 / 2$ & $9.28 \mathrm{bc}$ & $12.44 \mathrm{ab}$ & $8.04 \mathrm{c}-\mathrm{e}$ & $11.67 \mathrm{ab}$ \\
5 & $2 / 2$ & $5 / 2$ & $11.28 \mathrm{a}$ & $10.22 \mathrm{de}$ & $11.05 \mathrm{a}$ & $8.33 \mathrm{~d}$ \\
6 & $10 / 2$ & $13 / 2$ & $8.79 \mathrm{~b}-\mathrm{d}$ & $12.00 \mathrm{bc}$ & $7.77 \mathrm{c}-\mathrm{f}$ & $11.33 \mathrm{ab}$ \\
7 & $11 / 2$ & $14 / 2$ & $8.44 \mathrm{~cd}$ & $13.56 \mathrm{a}$ & $6.18 \mathrm{f}$ & $12.67 \mathrm{a}$ \\
8 & $9 / 2$ & $13 / 2$ & $7.94 \mathrm{~cd}$ & $10.53 \mathrm{c}-\mathrm{e}$ & $6.03 \mathrm{f}$ & $9.22 \mathrm{~cd}$ \\
9 & $13 / 2$ & $17 / 2$ & $11.28 \mathrm{a}$ & $10.33 \mathrm{de}$ & $10.44 \mathrm{ab}$ & $11.43 \mathrm{ab}$ \\
10 & $13 / 2$ & $14 / 2$ & $9.28 \mathrm{bc}$ & $7.39 \mathrm{gh}$ & $8.64 \mathrm{~cd}$ & $8.17 \mathrm{~d}$ \\
11 & $14 / 2$ & $22 / 2$ & $7.28 \mathrm{~d}$ & $5.78 \mathrm{i}$ & $6.05 \mathrm{f}$ & $3.33 \mathrm{ef}$ \\
12 & $16 / 2$ & $20 / 2$ & $9.28 \mathrm{bc}$ & $11.61 \mathrm{~b}-\mathrm{d}$ & $8.69 \mathrm{~cd}$ & $10.44 \mathrm{bc}$ \\
13 & $16 / 2$ & $18 / 2$ & $7.42 \mathrm{~d}$ & $6.06 \mathrm{hi}$ & $3.70 \mathrm{~g}$ & $2.61 \mathrm{f}$ \\
14 & $15 / 2$ & $17 / 2$ & $8.28 \mathrm{~cd}$ & $5.56 \mathrm{i}$ & $6.42 \mathrm{ef}$ & $4.59 \mathrm{e}$ \\
15 & $17 / 2$ & $20 / 2$ & $11.28 \mathrm{a}$ & $8.17 \mathrm{fg}$ & $11.19 \mathrm{a}$ & $8.50 \mathrm{~d}$ \\
\hline
\end{tabular}

F- Yield/ shrub (kg) Seed length, Seed width (cm) and Seed weight (g):

Data presented in Table 8 showed significant variation among female tested shrubs under the present study. Average yield varied from $1 \mathrm{~kg}$ per shrub to 3.5 $\mathrm{kg}$ per shrub. The highest average yield was recorded in Shrub No. 12 during first and second seasons. Similarly, Benzioni et al., (1999), Abu El-Khashab et al., (2007) 
and El-Said (2010) detected variation in yield of jojoba shrubs at different season Brown and Hall (1982) mentioned that structure and fertility of several jojoba shrubs recorded a wide variation from year to year due to climatic effect.

Data in Table 8 show that among the studied female tested shrubs, shrubs No. 6 was the highest seed length during the first season. While, the shrub No. 11 gave the highest seed length in the second season. Concerning the seed width, the shrub No. 13 gave the highest seed width in the first season. Whereas, the shrub No. 12 gave the highest seed width in the second season. As for seed weight (gm), the highest values were obtained shrub No. 12 in the second season. These results are nearly in the same line with these obtained by Benzioni et al. (1999); Abu El-Khashab et al. (2007) and El-Said (2010). Also, El-Torky et al. (2004) found that clear differences between clones. Furthermore, Yermanos (1982) indicate that variation in yield and seed characteristics from one year to the next due to genotype and environmental factors such as temperature.

Table 8. Yield, seed length $(\mathrm{cm})$ estimation, seed width $(\mathrm{cm})$ and seed weight (gm in the 15 trees females Jojoba shrubs during seasons $2014 \& 2015$.

\begin{tabular}{|c|c|c|c|c|c|c|c|c|}
\hline \multirow{2}{*}{$\begin{array}{l}\text { No. of } \\
\text { shrubs }\end{array}$} & \multicolumn{2}{|c|}{ Yield/ shrub (kg) } & \multicolumn{2}{|c|}{ Seed length $(\mathrm{cm})$} & \multicolumn{2}{|c|}{ Seed width (cm) } & \multicolumn{2}{|c|}{ Seed weight (gm) } \\
\hline & 2014 & 2015 & 2014 & 2015 & 2014 & 2015 & 2014 & 2015 \\
\hline 1 & 1.50 & 2.00 & $1.47 \mathrm{ef}$ & $1.49 \mathrm{f}$ & $1.18 \mathrm{a}-\mathrm{c}$ & $1.17 \mathrm{ab}$ & $0.96 \mathrm{~cd}$ & $1.12 \mathrm{de}$ \\
\hline 2 & 2.00 & 1.50 & $1.74 \mathrm{bc}$ & $1.71 \mathrm{bc}$ & $1.16 \mathrm{bc}$ & $1.18 \mathrm{ab}$ & $1.05 \mathrm{c}$ & $1.39 \mathrm{ab}$ \\
\hline 3 & 1.50 & 1.00 & $1.79 \mathrm{~b}$ & $1.53 \mathrm{ef}$ & $0.97 \mathrm{de}$ & $1.20 \mathrm{ab}$ & $0.83 \mathrm{~d}$ & $1.20 \mathrm{~cd}$ \\
\hline 4 & 1.50 & 1.50 & $1.77 \mathrm{bc}$ & $1.55 \mathrm{ef}$ & $1.19 \mathrm{ab}$ & $1.20 \mathrm{ab}$ & $1.31 \mathrm{~b}$ & $1.21 \mathrm{~cd}$ \\
\hline 5 & 2.50 & 1.50 & $1.78 \mathrm{bc}$ & $1.57 \mathrm{de}$ & $1.15 b c$ & $1.15 \mathrm{ab}$ & $1.31 \mathrm{~b}$ & $1.11 \mathrm{de}$ \\
\hline 6 & 1.50 & 1. 50 & $2.10 \mathrm{a}$ & $1.60 \mathrm{de}$ & $1.15 b c$ & $1.03 \mathrm{c}$ & $1.25 \mathrm{~b}$ & $0.87 f$ \\
\hline 7 & 1.00 & 1.00 & $1.65 \mathrm{~b}-\mathrm{e}$ & $1.76 \mathrm{ab}$ & $1.10 \mathrm{~b}-\mathrm{d}$ & $1.13 \mathrm{~b}$ & $0.98 \mathrm{~cd}$ & $1.20 \mathrm{~cd}$ \\
\hline 8 & 1.50 & 0.50 & $1.53 \mathrm{ef}$ & $1.78 \mathrm{ab}$ & $1.15 b c$ & $1.19 \mathrm{ab}$ & $1.04 \mathrm{c}$ & $1.35 \mathrm{ab}$ \\
\hline 9 & 2.00 & 3.00 & $1.44 \mathrm{f}$ & $1.71 \mathrm{bc}$ & $1.10 \mathrm{~b}-\mathrm{d}$ & $1.16 \mathrm{ab}$ & $0.96 \mathrm{~cd}$ & $1.35 \mathrm{ab}$ \\
\hline 10 & 2.50 & 1.50 & $1.60 c-f$ & $1.76 \mathrm{ab}$ & $1.00 \mathrm{de}$ & $1.16 \mathrm{ab}$ & $0.95 \mathrm{~cd}$ & $1.32 \mathrm{bc}$ \\
\hline 11 & 1.00 & 2.00 & $1.60 \mathrm{c}-\mathrm{f}$ & $1.81 \mathrm{a}$ & $1.05 \mathrm{~cd}$ & $0.99 \mathrm{c}$ & $0.98 \mathrm{~cd}$ & $1.01 \mathrm{e}$ \\
\hline 12 & 3.00 & 3.50 & $1.42 \mathrm{f}$ & $1.73 \mathrm{ab}$ & $1.30 \mathrm{a}$ & $1.22 \mathrm{a}$ & $1.52 \mathrm{a}$ & $1.46 \mathrm{a}$ \\
\hline 13 & 1.00 & 2.00 & $1.73 b-d$ & $1.64 \mathrm{~cd}$ & $1.07 \mathrm{~b}-\mathrm{d}$ & $1.20 \mathrm{ab}$ & $0.84 \mathrm{~d}$ & $1.44 \mathrm{ab}$ \\
\hline 14 & 1.50 & 2.00 & $1.55 \mathrm{~d}-\mathrm{f}$ & $1.54 \mathrm{ef}$ & $1.05 \mathrm{~cd}$ & $0.97 \mathrm{c}$ & $1.02 \mathrm{c}$ & $0.83 \mathrm{f}$ \\
\hline 15 & 2.50 & 1.50 & $1.80 \mathrm{~b}$ & $1.58 \mathrm{de}$ & $0.90 \mathrm{e}$ & $1.17 \mathrm{ab}$ & $0.84 \mathrm{~d}$ & $1.21 \mathrm{~cd}$ \\
\hline
\end{tabular}

Values in the same column having different letters showed statistically significant differences $(\mathrm{P}<0.05)$.

\section{G- Number of ridges, Number of grooves, seed oil content and moisture content:}

The results presented in Table 9 show that the female tested shrub No. 5 had the highest number of ridges during both seasons. As regard to the No. of grooves, It was obviously cleared in Table 9 that No. of grooves ranged between $3-4$ grooves in both studied seasons. Concerning seed oil, the shrub No.13 was the highest shrub of oil content $(56.00 \%)$ followed by shrub No. 2 (54.33) in the first season. While the season 2015 had the highest percentage of oil in shrub No. 11 $(61.17 \%)$ and the lowest percentage of oil content in shrub No. 14 (39.11\%) during the first season. While, the shrub No. 3 (49.50) gave the lowest in the second season. As for moisture content, The moisture content in
Table (9), moisture content ranging from $7.59 \%$ to $15.59 \%$ in the first season. Whereas, in the second one, moisture content ranging from $7.87 \%$ to $10.89 \%$ The Shrub No. 7 was the lowest value in moisture content compared with the other shrubs under this investigation at season 2014. On the other hand, the shrub No. 5 was the lowest value in moisture content $(7.87 \%)$ and shrub No. 14 and 15 were the highest value in moisture content in season 2014. While, the shrub No. 4 was the highest value in moisture content in season 2015 These results are in line with those reported by Benzioni et al. (1999); Uilger et al. (2002); Abu El-Khashab et al. (2007) and Shereen et al. (2010). Also, Botti et al. (1998) found that the differences were present among the shrubs in the oil content.

Table 9. Number of ridges, number of grooves along with seed, seed oil content and Moisture content \% in the 15 trees females Jojoba shrubs during seasons 2014 \& 2015.

\begin{tabular}{|c|c|c|c|c|c|c|c|c|}
\hline \multirow{2}{*}{$\begin{array}{l}\text { No. of } \\
\text { shrubs }\end{array}$} & \multicolumn{2}{|c|}{ No. of ridges } & \multicolumn{2}{|c|}{ No. of grooves } & \multicolumn{2}{|c|}{ Seed oil \% } & \multicolumn{2}{|c|}{ Moisture content $\%$} \\
\hline & 2014 & 2015 & 2014 & 2015 & 2014 & 2015 & 2014 & 2015 \\
\hline 1 & $15.44 \mathrm{e}$ & $14.44 \mathrm{ef}$ & $3.00 \mathrm{~b}$ & $3.00 \mathrm{~b}$ & $50.74 \mathrm{c}$ & $51.12 \mathrm{c}-\mathrm{e}$ & $12.43 \mathrm{bc}$ & $10.32 \mathrm{ab}$ \\
\hline 2 & $18.33 \mathrm{bc}$ & $17.33 \mathrm{bc}$ & $4.00 \mathrm{a}$ & $4.00 \mathrm{a}$ & $54.33 \mathrm{ab}$ & $53.35 \mathrm{~b}-\mathrm{d}$ & $10.85 \mathrm{de}$ & $8.53 \mathrm{~d}-\mathrm{g}$ \\
\hline$\overline{3}$ & $16.44 d$ & $17.33 \mathrm{bc}$ & $3.00 \mathrm{~b}$ & $3.00 \mathrm{~b}$ & $44.42 \mathrm{de}$ & $49.50 \mathrm{e}$ & $11.93 \mathrm{~b}-\mathrm{d}$ & $9.25 \mathrm{~b}-\mathrm{e}$ \\
\hline 4 & $17.44 \mathrm{~cd}$ & $16.44 \mathrm{~cd}$ & $3.00 \mathrm{~b}$ & $3.00 \mathrm{~b}$ & $50.16 \mathrm{c}$ & $51.16 \mathrm{c}-\mathrm{e}$ & $12.63 \mathrm{bc}$ & $10.89 a$ \\
\hline 5 & $20.22 \mathrm{a}$ & $18.44 \mathrm{a}$ & $3.00 \mathrm{~b}$ & $3.00 \mathrm{~b}$ & $53.18 \mathrm{a}-\mathrm{c}$ & $54.10 \mathrm{bc}$ & $10.09 \mathrm{ef}$ & $7.87 \mathrm{~g}$ \\
\hline 6 & $18.56 \mathrm{~b}$ & $18.33 \mathrm{ab}$ & $3.00 \mathrm{~b}$ & $3.00 \mathrm{~b}$ & $50.81 \mathrm{c}$ & $50.56 \mathrm{c}-\mathrm{e}$ & $13.05 \mathrm{~b}$ & $9.43 \mathrm{~b}-\mathrm{d}$ \\
\hline 7 & $12.33 \mathrm{~g}$ & $11.11 \mathrm{~h}$ & $3.00 \mathrm{~b}$ & $3.00 \mathrm{~b}$ & $54.11 \mathrm{ab}$ & $52.17 \mathrm{~b}-\mathrm{e}$ & $7.59 \mathrm{~h}$ & $8.32 \mathrm{~d}-\mathrm{g}$ \\
\hline 8 & $15.44 \mathrm{e}^{\circ}$ & $15.44 \mathrm{de}$ & $3.00 \mathrm{~b}$ & $3.00 \mathrm{~b}$ & $52.65 \mathrm{bc}$ & $53.10 \mathrm{~b}-\mathrm{d}$ & $8.73 \mathrm{gh}$ & $7.91 \mathrm{~g}$ \\
\hline 9 & $14.44 \mathrm{ef}$ & $13.44 \mathrm{f}$ & $4.00 \mathrm{a}$ & $4.00 \mathrm{a}$ & $52.87 \mathrm{a}-\mathrm{c}$ & $52.40 \mathrm{~b}-\mathrm{e}$ & $8.31 \mathrm{gh}$ & $8.13 \mathrm{e}-\mathrm{g}$ \\
\hline 10 & $15.22 \mathrm{ef}$ & $14.44 \mathrm{ef}$ & $3.00 \mathrm{~b}$ & $3.00 \mathrm{~b}$ & $50.11 \mathrm{c}$ & $51.32 \mathrm{c}-\mathrm{e}$ & $10.82 \mathrm{de}$ & $8.92 \mathrm{c}-\mathrm{g}$ \\
\hline 11 & $11.22 \mathrm{~h}$ & $10.11 \mathrm{~h}$ & $3.00 \mathrm{~b}$ & $3.00 \mathrm{~b}$ & $46.36 \mathrm{~d}$ & $61.17 \mathrm{a}$ & $11.76 \mathrm{~cd}$ & $9.15 \mathrm{c}-\mathrm{f}$ \\
\hline 12 & $15.33 \mathrm{ef}$ & $15.33 \mathrm{de}$ & $4.00 \mathrm{a}$ & $4.00 \mathrm{a}$ & $52.42 \mathrm{bc}$ & $53.78 \mathrm{bc}$ & $9.37 \mathrm{fg}$ & $8.01 \mathrm{fg}$ \\
\hline 13 & $17.33 \mathrm{~cd}$ & $16.44 \mathrm{~cd}$ & $4.00 \mathrm{a}$ & $4.00 \mathrm{a}$ & $56.00 \mathrm{a}$ & $55.25 \mathrm{~b}$ & $7.72 \mathrm{~h}$ & $7.93 \mathrm{~g}$ \\
\hline 14 & $14.33 \mathrm{f}$ & $13.33 \mathrm{fg}$ & $3.00 \mathrm{~b}$ & $3.00 \mathrm{~b}$ & $39.11 \mathrm{f}$ & 49.80de & $15.59 a$ & $9.82 \mathrm{bc}$ \\
\hline 15 & $12.55 \mathrm{~g}$ & $12.33 \mathrm{~g}$ & $4.00 \mathrm{a}$ & $4.00 \mathrm{a}$ & $41.71 \mathrm{ef}$ & $51.15 \mathrm{c}-\mathrm{e}$ & $14.50 \mathrm{a}$ & $8.10 \mathrm{e}-\mathrm{g}$ \\
\hline
\end{tabular}

Values in the same column having different letters showed statistically significant differences $(\mathrm{P}<0.05)$. 


\section{H- DNA fingerprint:}

Random amplified polymorphic DNA (RAPD-PCR) procedure

A set of five random 10-mer primers (Table, 10) were used in the detection of polymorphism among evaluated jojoba strains.

Polymorphism detected by RAPD marker:

Five RAPD primers were tested with the DNA of 15 jojoba strains. These primers produced multiple band profile which ranged from 8 to 23amplicon (Table 10). Total number of amplicons amplified by the five primers was 75 with an average 15 amplicon/primer (Fig 3). The number of polymorphic bands ranged from 5 (OP-Z03) to 20 (OP-A07), representing percentage of polymorphism ranged from $41.6 \%$ (OP-Z03) to $86.9 \%$ (OP-A07). The size of the amplified bands varied according to the used primers, it was ranged from $55 \mathrm{bp}$ to $2269 \mathrm{bp}$.

Table 10. Polymorphic, monomorphic, total amplicon and percentage of polymorphism as detected by Five RAPD primers.

\begin{tabular}{l|c|c|c|c|}
\hline Primer & $\begin{array}{c}\text { Total no. of } \\
\text { implications }\end{array}$ & $\begin{array}{c}\text { Monomorphic } \\
\text { implications }\end{array}$ & $\begin{array}{c}\text { Polymorphic } \\
\text { implications }\end{array}$ & $\begin{array}{c}\text { Percentage of } \\
\text { polymorphism }\end{array}$ \\
\hline OP- A-07 & 23 & 3 & 20 & $86.90 \%$ \\
OP- A-18 & 19 & 4 & 15 & $78.90 \%$ \\
OP- C-04 & 13 & 3 & $70.90 \%$ \\
OP- C-19 & 8 & 1 & 5 & $87.50 \%$ \\
OP-Z-03 & 12 & 7 & 57 & $41.60 \%$ \\
Total & 75 & 18 & 11.4 & \\
Average & 15 & 3.5 & \\
\hline
\end{tabular}

Table 11. Genetic similarity among fifteen jojoba strains detected by RAPD marker.

\begin{tabular}{|c|c|c|c|c|c|c|c|c|c|c|c|c|c|c|}
\hline & 1 & 2 & 3 & 4 & 5 & 6 & 7 & 8 & 9 & 10 & 11 & 12 & 13 & 14 \\
\hline$\frac{1}{2}$ & 0.000 & & & & & & & & & & & & & \\
\hline 3 & $\begin{array}{l}0.083 \\
0.333\end{array}$ & 0.458 & & & & & & & & & & & & \\
\hline 4 & 0.333 & 0.375 & 0.625 & & & & & & & & & & & \\
\hline 5 & 0.208 & 0.583 & 0.583 & 0.417 & & & & & & & & & & \\
\hline 6 & 0.125 & 0.417 & 0.333 & 0.500 & 0.625 & & & & & & & & & \\
\hline 7 & 0.333 & 0.625 & 0.542 & 0.458 & 0.667 & 0.583 & & & & & & & & \\
\hline 8 & 0.208 & 0.583 & 0.500 & 0.583 & 0.625 & 0.875 & 0.750 & & & & & & & \\
\hline 9 & 0.083 & 0.458 & 0.458 & 0.542 & 0.667 & 0.667 & 0.792 & 0.750 & & & & & & \\
\hline 10 & 0.042 & 0.500 & 0.417 & 0.250 & 0.708 & 0.625 & 0.750 & 0.708 & 0.583 & & & & & \\
\hline 11 & 0.125 & 0.500 & 0.583 & 0.333 & 0.708 & 0.375 & 0.750 & 0.625 & 0.750 & 0.708 & & & & \\
\hline 12 & 0.00 & 0.625 & 0.375 & 0.375 & 0.583 & 0.667 & 0.625 & 0.833 & 0.542 & 0.667 & 0.500 & & & \\
\hline 13 & 0.042 & 0.583 & 0.417 & 0.333 & 0.625 & 0.625 & 0.667 & 0.792 & 0.583 & 0.625 & 0.625 & 1.000 & & \\
\hline 14 & 0.042 & 0.500 & 0.583 & 0.333 & 0.792 & 0.458 & 0.667 & 0.625 & 0.750 & 0.542 & 0.792 & 0.500 & 0.625 & \\
\hline 15 & 0.083 & 0.292 & 0.625 & 0.375 & 0.500 & 0.333 & 0.542 & 0.500 & 0.458 & 0.333 & 0.667 & 0.375 & 0.500 & 0.583 \\
\hline
\end{tabular}

\section{Genetic similarity:}

The genetic similarity ranged from zero ( $\mathrm{T} 1$ and $\mathrm{T} 12)$ to 1 (T12 and T13). A high value of genetic similarity $(0.875)$ was also observed between the strains (T8 and T6) followed by 0.792 between (T5 \& T15, T8 \& T13 and T11\&T14), respectively (Table 11) reflecting a common genetic background. Gupta et al. (1994) and Attia et al., (2012), they get good amplification patterns with other genomes derived from different plant species using (GACA) 4 which correspond to Mic3, On the other hand, the 3pinned ignition (Mick 4, Mick 5 and Mick 6) was less repeatable. Only one primer (Mic4) showed nine polymers amlicons out of twenty-two (40.9\%) (Abu El-Khashab et al. 2007 and Gaber et al., 2007).

Genetic marker has been demonstrated to be associated a phenotypic trait of interest, it can be used as a selection target to obtain an indirect response in the trait Breseghello and Sorrells, (2006). Market - trait are reported in various agronomical and horticultural crops (Tayebe et al. 2013). On the other hand, strains (T9, T10, T13, T14 and T15) showed a lower value of genetic similarity withT1 $(0.08,0.04,0.04,0.04$ and 0.08 , respectively); another strains also recorded low value of genetic similarity $(0.25,0.33$, $0.37,0.33,0.33$ and 0.37 ) with T4 (T10, T11, T12, T13, T14 and $\mathrm{T} 15)$, respectively.

Generally, genetic similarity value was low among the investigated strains. These variations observed in genetic similarity could be attributed to the effectiveness of origin of these strains as a seedy plant.

\section{Cluster analysis:}

Dendrogram obtained from UPGMA cluster analysis of genetic distances Fig (4) revealed that, the strains were divided into five clusters. The first cluster was divided into two groups each. The first group included (T13 and T12); while the second one collected (T6 and T8). The second cluster was divided into three groups, one of them involved (T7 and T9). The second group contained T11 and T4; while the third group involved only strain T5. Strain T2 was found alone in the third cluster; the same was true for strain T1 which located alone the fifth cluster. Meanwhile, the fourth cluster grouped strains T3, T4 and T15.

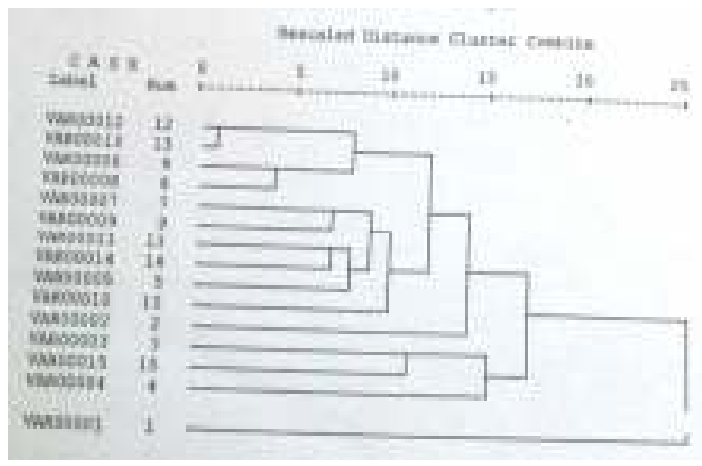

Fig. 3. Dendrogram using Average Linkage (Between Groups).

Dendrogram using Average Linkage (Between Groups 


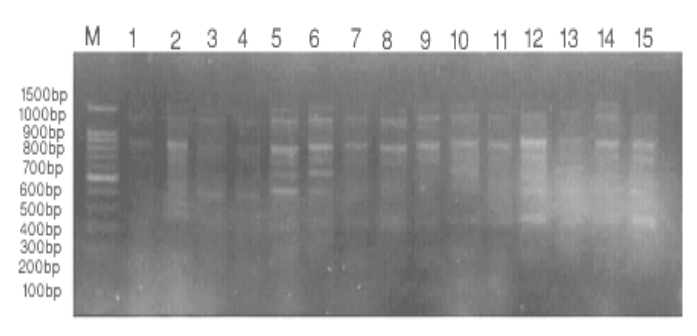

OP-A18

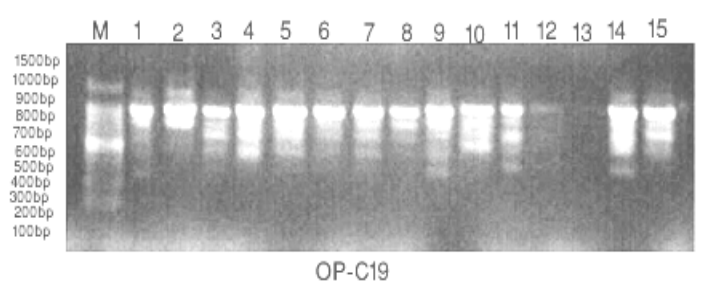

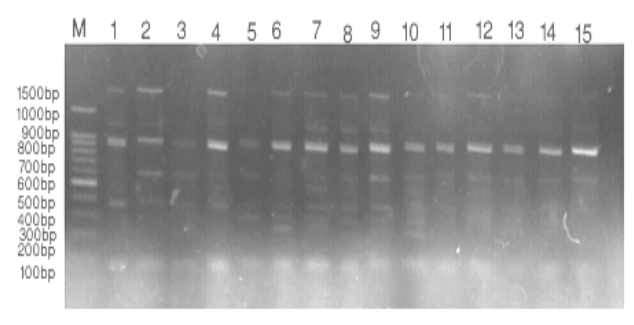

OP-A07

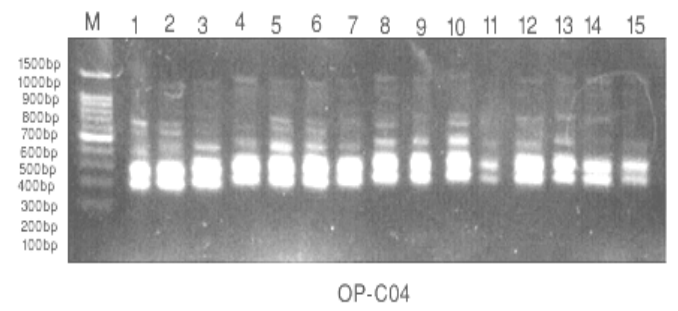

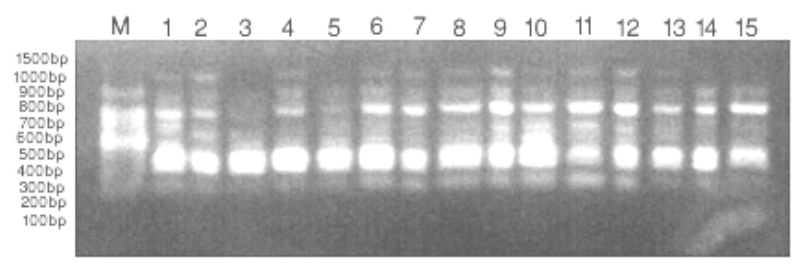

OP-Z03

Fig. 4. RAPD-PCR analysis of different 15 trees females cultivated.

1- T1, 2- T2, 3-T3, 4-T4, 5-T5, 6- T6, 7-T7, 8- T8, 9-T9, 10 -T10, 11-T11, 12- T12, 13- T13, 14- T14 and 15-T15.

\section{CONCLUSION}

It could be concluded from the aforementioned results, that the five Jojoba genotypes were significantly different in morphological characteristics, physiological aspects genetic markets and chemical constituents.

\section{ACKNOWLEDGMENT}

We would like to express our deep gratitude to Egyptian Army and Hort. Res. Inst., especially Prof. Dr. Nahla Abd EL-Fatah.

\section{REFERENCES}

Abu El-Khashab, A. M.; Awad, A. Nahla and El-Iraqy, M.A. (2007). Evaluation and selection of some Jojoba (Simmondisia chinensis clones under Giza Governorate. The proceeding of the third Conf. of Sustain. Agric. Develop. Fac. of Agric., Fayoum Univ., 12-14 Nov.

Al-Ani, H. A., strain B. R. and Mooney, H.A. (1972). The physiological ecology diverse populations of the desert shrub (Simmondsia chinensis). J. Ecol., 60: 41-57.

Association of Official Agriculture Chemists (2012). Official Methods of Analysis. AOAC. 14 ${ }^{\text {th }}$ Ed. Washington.

Attia, M. M.; M. Hussein, A.; Hussein, I. A.; El-Salmony, Y. M. and Afiah, S.A. (2012). Molecular discrimination among diverse grapevine genotypes by RAPD markers in relation to drought. J. Biol. Chem. Environ. Sci., 7 (1): 339-346. www.acepsag.org.
Ayanoglu, F. (2000). Jojoba (Simmondisia chinensis (Link) Schneider) and its cultivation of Jojoba Anadolu, 10(1):18-30.

Ayerza, R., (1996). Evaluation of eight Jojoba clones for rooting capacity, plant volume, seed yield and wax quality and quantity. Proceedings of the $9^{\text {th }}$ International Conference on Jojoba and its Uses, Catamarca, Argentina:1-3.

Benzioni, A., (1995). Jojoba domestication and commercialization in Israel. Hort. Rev., 17: 233-266.

Benzioni, A., (1997). Jojba (New crop fact sheet). (C.F. computer search): $1-7$.

Benzioni, A., Shiloh, E. and Ventura, M. (1999). Yield parameters in young jojoba plants and their relation to actual yield in later years. Ind.Crops Prod.10:8589.

Botti, C., Doussoulin, E., X. Lopez., Cruz, P. andCanaves, L. (1996). Selection and evaluation of clonal Jojoba germplasm: 1. Young plants. In: Princen, L.H. Rossi, C.(Eds.), Proc. $9^{\text {th }}$ Int. Conf. on New Industrial Crops and products,25-30 September 1994, Catamarca, Argentina, pp.. 65-70.

Botti, C., Prat, L., Palzkill, D. and Canaves, L., (1998). Evaluation of jojoba clones grown under water and salinity stresses in Clile. Ind, Crops Prod., 9:39-45.

Breseghello, F. and Sorrells, M. (2006). Association analysis as a strategy for improvement of quantitative traits in plants. Crop Sci.46:1323-1330. 
Brown, C. and N. Hall (1982). An Economic Evaluation of Jojoba Production in Australia. Bureau of Agricultural Economics, Canberra, No. 72:1-24.

Chen, P. K.; Fan, C. J.; Brien W. O. and Venketeswaran, S. (1985). Per flavoring sex determination: An aid to Jojoba propagation pre- $6^{\text {th }}$ Inter. Conf. Jojoba and its uses, Ben Gurion Univ. of the Negev, Beer-Shera, Israel.

Dice, L. R. (1945). Measures of the amount of ecologic association between species. Ecology, 26: 297302.

Duncan, B. D. (1955). Duncan' Multiple Range and Multiple F Tests. Biometrics, 11:1-42.

El. Torky, M. G.; Shaein, A.H.; Ola A. El-Shennawy; ElFadly, E. M. (2004). Studies on Jojoba (Simmondisia chinensis (Link) Schneider): П-Studies on some vegetative and flowering characteristics. J. Agric. Sci., Mansoura Univ., 29(12): 7201-7215.

El-Sayed, M. EL. H. (2010). Studies of some local strains of Jojoba. Ph.D. Thesis, Faculty of Agric., Mansoura University, Egypt.

Gaber, A.; Heba, M.M. El-Maraghy; Aly, M.A.M.; Nahed, A.K. Rashed and Gamal EL-Din, A.Y. (2007). Induction of somatic embryogenesis and DNA fingerprinting of Jojoba. Arab J. Biotech., 10(2): 341354.

Gupta, M, Chy; Y. S., Remero-Severson, J. and Owen, J. L. (1994). Amplification of DNA markers from evolutionarily diverse genomes using single primers of simple sequence repeats. Theor. Apple. Genet., 89: 988-1006.

Hassan, A. (2007). Morphological and chemical studies on Jojoba plant. M.Sc. Thesis, Pomology, Faculty of Agriculture, Cairo University.

Hawson, M.G. (1985). Jojoba in western Ausralia. Proceedings of the Sixth International Conference Jojoba and its Uses, Beer-Sheva, Israel: 51-58.

Hogan, L.; G. W. Lee; D. A. Palzkill and W.R. Feldman(1980). Jojoba: A new Horticultural crop for arid regions. HortScience, 15(2):114.

Hosseini-Mazinani, S. M.; Samaee, S. M.; Sadeghi, H. and Caballero, J. M. (2004). Evaluation of olive germplasm in Iran on the basis of morphological traits: assessment of Zard and Rowghani cultivars. Acta Hort., 634:145-15.

Kohorn, L. U. (1994). Shoot morphology and reproduction in Jojoba: Advantage of sexual dimorphism .Ecology, 75(8):2384-2394.
Kohorn, L. U. (1995). Geographic variation in the occurance and extent of sexual dimorphism indioecious shrub, simmondsia chinensis Oikos, 74(1):137-145.

Milthorpe, $\mathrm{P}(2006)$. Evaluation of Jojoba germplasm in different environments. A report for the Rural Industries Research and development Corporation, Australian Government. RIRDC project No DAN206 A, publication No. 5/184:1-14.

Palzkill, D. A. (1987). Review of some naturally occurring variability in Jojoba and its use in cultivar development. In: Proc. Reunion international de Jojoba, 17-22June,Asunciion, Paraguay(ALAJO):1-8.

Ramonet-Razcon, R. (1986). Estudio de la correlation y regression entre characteristics cuantitativas la costa de Hermosillo, son. Tesis, Escuela de agricultura y Ganaderia, de Sonora, Hermosillo, Sonora.

Ramonet-Razcon, R. (1988). Selection criteria and evaluation procedures for Jojoba plant improvement. Proceedings of the Seventh International Conference on Jojoba and its Uses. Phoenix, Arizona, 1:60-68.

Shaheen, S. A.; Aly A. A. and Essa K.B. (2010). Evaluation of some female Jojoba (Simmondsia chinensis (Link) Schneider). Shrubs under south El-Tahrir region conditions. J. Plant Prod., Mansoura Univ., 1(12): 1691-1705.

Snedecor, G. W. and Cocharn R. R. (1980). Statistical Methods. $7^{\text {th }}$ ed. Iowa. State Univ. Press, Ames, Iowa, USA:507.

Tayebe, B.; Mohammad, A. N.; Ramin, J. N.; Sakine, F. and Fatemeh, K. (2013). Identification of simple sequences repeat (SSR) nformative markers associated with important traits in pomegranate (Punica granatum L.). International Journal of Agronomy and Plant Production, Vol.,4 (3): 575-583.

Ulger, S; Akdesir, O. and Baktir, I. (2002). Selection of promising Jojoba Simmondisia chinensis (Link) Schneider) types in terms of yield and oil content. Turk J Agric for(26): 319-322.

Williams, J. G. K., Kubelik., A.R.K.; Livak., T.; Rafalski, J.A. and Tingey, S.V. (1990). Nucleic Acids Research. 18: 6531-6539.

Yermanos, D. M. (1982). Performance of Jojoba under cultivation between 1973 and 1982, information developed at the University of California, Riverside. In: Elias- Cenik, A.(Ed), Jojoba and its Uses, Through 1982, proceedings of the Fifth International Conference . University of Arizona, Tucson, Az: 200-201.

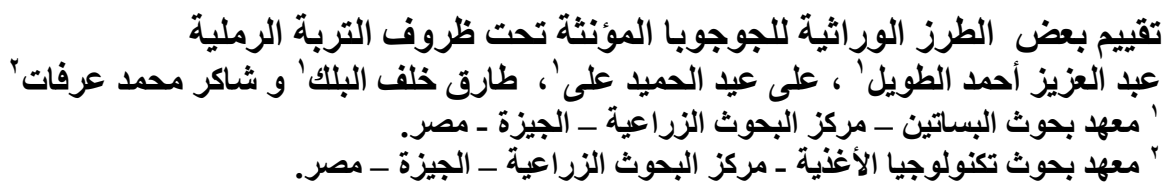

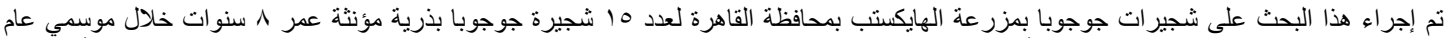

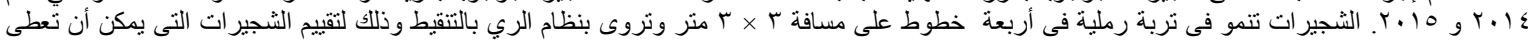

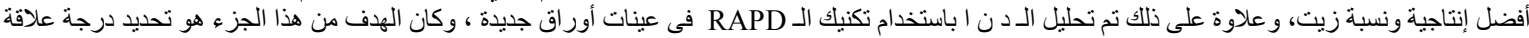

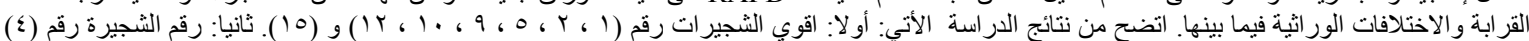

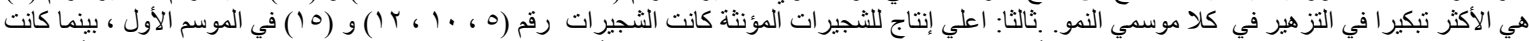

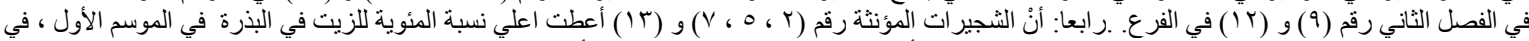

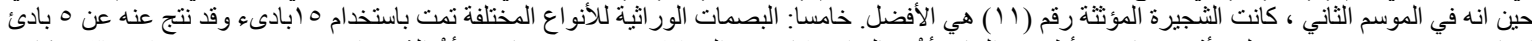

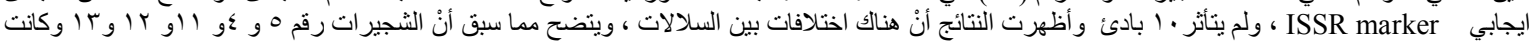

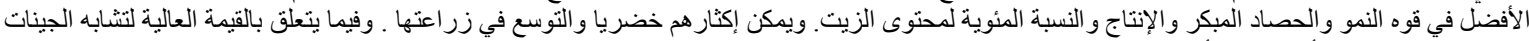

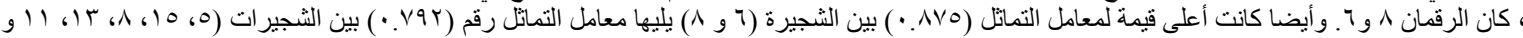

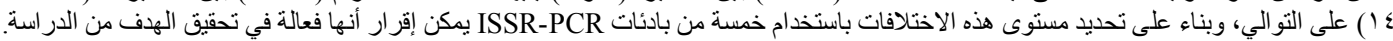

